\title{
Penerapan Pupuk Urea pada Tumpangsari Jagung "Double Row" dan Kacang Tanah Terhadap Pertumbuhan dan Hasil Jagung (Zea mays L.)
}

\author{
Application of Urea Fertilizer on Corn "Double Row” and Peanut \\ Intercropping on The Growth and Results of Corn (Zea Mays L. )
}

\section{Margaretha S. Gadmor*, Niar Nurmauli, Paul B. Timotiwu, dan Herawati Hamim}

Jurusan Agroteknologi Fakultas Pertanian Universitas Lampung Jl.

Prof. Dr. Soemantri Brojonegoro No. 1 Bandar Lampung 35145

Email :margarethasw19@gmail.com

\begin{abstract}
The study aims to determine: (1) response growth and result of corn and peanut on monoculture and intercropping; (2) an optimal urea doze on growth and result of corn and peanut. Research did from July to November 2014 in Laboratory of Integrated, Faculty of Agriculture, University of Lampung. The research used complete Random Group Design with Triple Multiply. Homogenity of variance was tested by Bartlett test. Separation of median is done by using the test Polynomial Orthogonal with real level $5 \%$. The result showed that picking of corn per hectar for monoculture higher than intercropping but the other variable wasn't really different. Peanut monoculture higher than intercropping for number of pods, weight of 100 grains, and production of seed per hectar but for plant height and greening level, pattern levels of intercropping higher than monoculture, and there were not find an optimal urea doze for corn on intercropping of corn "double row" and peanut.
\end{abstract}

Keywords : corn, intercropping, peanuts, urea

Diterima: 14 Juni 2016, disetujui: 21 Juli 2017

\section{PENDAHULUAN}

Jagung merupakan salah satu tanaman pangan penting kedua setelah padi yang memiliki fungsi multiguna, tidak hanya digunakan sebagai bahan pangan tetapi dapat digunakan sebagai pakan ternak dan bahan baku industri. Permintaan jagung sebagai pakan akan terus meningkat seiring dengan meningkatnya industri pakan ternak (Tangedjaja, 2011). Namun, produksi jagung di Indonesia belum mampu memenuhi permintaan jagung yang semakin meningkat.

Pada tahun 2013, produksi jagung mengalami penurunan sebesar 0,81 juta ton dibanding tahun 2012 (Badan Pusat Statistik, 2014). Penurunan tersebut membuat pemerintah Indonesia masih melakukan impor jagung dari beberapa negara untuk memenuhi permintaan jagung yang meningkat setiap tahunnya. Untuk itu usaha yang dapat dilakukan dalam memenuhi permintaan jagung antara lain dengan upaya diversifikasi pertanian. Upaya tersebut dapat dilakukan dengan penerapan pola tanam tumpangsari.

Tumpangsari adalah penanaman dua atau lebih tanaman dalam interval waktu yang berdekatan pada suatu lahan yang sama. Penanaman dengan pola tanam tumpangsaru dapat dilakukan pada tanaman semusim 


\section{Jurnal Penelitian Pertanian Terapan}

dengan tanaman semusim lainnya yang saling menguntungkan, seperti tanaman jagung dan kacang-kacangan (kacang tanah) (Jumin, 2010). Produksi jagung dalam pola tanam tumpangsari akan meningkat apabila terdapat kecocokan dengan tanaman selanya. Tanaman kacang-kacangan, dalam hal ini kacang tanah, adalah tanaman sela yang sesuai untuk diterapkan dalam pola tanam tumpangsari dengan tanaman jagung. Sebab, tanaman kacang tanah dapat membentuk bintil akan yang mampu memfiksasi nitrogen dari udara bebas secara simbiosis dengan bakteri Rhizobium sp. Sehingga kekurangan nitrogen pada jagung dapat terpenuhi.

Menurut Myrna dan Puji Lestari (2003), syarat tercapainya hasil jagung yang tinggi adalah ketersediaan unsur hara yang optimal seperti unsur hara nitrogen. Tanaman jagung menyerap unsur nitrogen dalam jumlah yang besar selama masa tanamnya mulai dari awal pertumbuhan sampai pada fase pengisian biji pada tongkol jagung sehingga secara terus menerus tanaman jagung selalu menyerap unsur $\mathrm{N}$ sehingga dengan pemberian pupuk urea pada tanaman jagung dapat meningkatkan hasil jagung (Lingga dan Marsono, 2008).

Penelitian ini bertujuan untuk: (1) mengetahui respon pertumbuhan dan hasil tanaman jagung dan kacang tanah dalam pola tanam monokultur dan tumpangsari "double row", (2) mengetahui dosis pupuk urea yang baik pada pertumbuhan dan hasil tanaman jagung dan kacang tanah.

\section{METODE PENELITIAN}

Penelitian dilaksanakan di Laboratorium Terpadu dan Laboratorium Ilmu Tanaman dari bulan Juli sampai dengan November 2014. Bahan-bahan yang digunakan adalah benih jagung varietas bisi 18, benih kacang tanah varietas kelinci, pupuk urea, pupuk $\mathrm{KCl}$, pupuk SP-36, furadan $3 \mathrm{G}$, insektisida Regent, dan fungisida Dithane m-45. Sedangkan alat-alat yang digunakan adalah cangkul, meteran, tali rafia, koret, alat tugal, alat semprot punggung, penggaris, oven, timbangan digital, selang, gunting, Kloropil Meter SPAD 502 plus, ember, dan alat tulis.

Penelitian ini dilakukan menggunakan Rancangan Kelompok Teracak Sempurna (RKTS) dengan 3 ulangan. Perlakuan terdiri atas monokultur jagung $\left(\mathrm{M}_{1}\right)$, monokultur kacang tanah $\left(\mathrm{M}_{2}\right)$, tumpangsari $0 \mathrm{~kg}$ urea $\left(\mathrm{U}_{0}\right)$, tumpangsari $50 \mathrm{~kg}$ urea $\left(\mathrm{U}_{1}\right)$, tumpangsari $100 \mathrm{~kg}$ urea $\left(\mathrm{U}_{2}\right)$, tumpangsari $150 \mathrm{~kg}$ urea $\left(\mathrm{U}_{3}\right)$, tumpangsari $200 \mathrm{~kg}$ urea $\left(\mathrm{U}_{4}\right)$, tumpangsari $250 \mathrm{~kg}$ urea $\left(\mathrm{U}_{5}\right)$, dan tumpangsari $300 \mathrm{~kg}$ urea $\left(\mathrm{U}_{6}\right)$. Homogenitas ragam diuji dengan uji Bartllet, sifat kemenambahan data diuji dengan uji Tukey, dan jika asumsi terpenuhi data dianalisis dengan sidik ragam. Pemisah nilai tengah menggunakan Orthogonal Polynomial pada taraf nyata $5 \%$. Setiap petak percobaan berukuran $3 \times 3 \mathrm{~m}$.

Pengamatan tinggi tanaman dilakukan setelah aplikasi pupuk urea yaitu 14 MST. Pengamatan tingkat kehijauan daun dilakukan pada saat tanaman memasuki umur 8 MST. Pengamatan bobot kering berangkasan jagung dilakukan pada saat pertumbuhan tanaman maksimum. Pengamatan umur berbunga jagung dilakukan pada saat tanaman jagung telah berbunga $50 \%$. Pengamatan panjang tongkol, diameter tongkol, bobot 100 buir KA 14\%, dan hasil pipilan jagung ton per hektar dilakukan pada saat panen. Pengamatan jumlah cabang produktif, jumlah polong total per tanaman, jumlah polong isi, bobot 100 butir 12\%, dan hasil biji kacang tanah ton per hektar dilakukan pada saat panen. jumlah cabang total, jumlah cabang produktif, jumlah polong total, dan jumlah polong isi dilakukan pada saat panen. Pengamatan bobot 100 butir kadar air $14 \%$ dan $12 \%$ diukur menggunakan timbangan analitik.

Bobot 100 butir $($ KA 14\% $)=\frac{100-\text { KA terukur } X}{100-14}($ bobot KA terukur $)$,

Bobot 100 butir $\left(\right.$ KA 12\%) $=\frac{100-\text { KA terukur } \mathrm{X}}{100-12}($ bobot KA terukur $)$ 
Gadmor, M.S dkk : Penerapan Pupuk Urea pada Tumpangsari Jagung “Double Row” dan Kacang Tanah...

\section{HASIL DAN PEMBAHASAN}

Hasil penelitian menunjukkan bahwa tumpangsari jagung "double row" dan kacang tanah berpengaruh terhadap hasil pipilan jagung, tetapi tidak berpengaruh pada variabel lainnya (Tabel 1).

Tabel 1. Penerapan pupuk urea pada tumpangsari jagung "double row" dan kacang tanah terhadap tinggi tanaman, tingkat kehijauan daun, umur berbunga, bobot kering brangkasan, panjang tongkol, diameter tongkol, bobot 100 butir, dan hasil pipilan jagung.

\begin{tabular}{|c|c|c|c|c|c|c|c|c|c|}
\hline \multicolumn{2}{|l|}{ Perbandingan } & $\mathrm{TT}$ & TKD & UB & $\mathrm{BKB}$ & PT & DT & B100 & $\mathrm{HP}$ \\
\hline \multicolumn{10}{|c|}{ 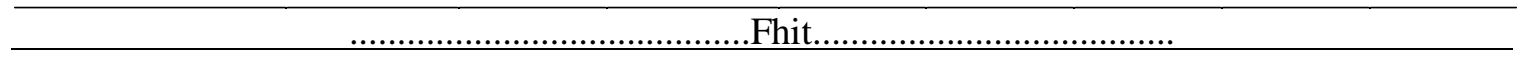 } \\
\hline \multicolumn{2}{|l|}{ C1: M vs TS } & $2,39^{\text {tn }}$ & $1,97^{\mathrm{tn}}$ & $0,91^{\text {tn }}$ & $1,15^{\mathrm{tn}}$ & $0,00^{\text {tn }}$ & $2,15^{\mathrm{tn}}$ & $2,49^{\text {tn }}$ & $38,10^{*}$ \\
\hline \multicolumn{2}{|l|}{ C2: Urea L } & $0,04^{\text {tn }}$ & $12,72^{*}$ & $4,34^{\mathrm{tn}}$ & $28,92^{*}$ & $0,73^{\text {tn }}$ & $1,64^{\mathrm{tn}}$ & $4,16^{\mathrm{tn}}$ & $97,38^{*}$ \\
\hline \multicolumn{2}{|l|}{ C3: Urea K } & $0,18^{\text {tn }}$ & $0,00^{\text {tn }}$ & $1,45^{\mathrm{tn}}$ & $8,02^{*}$ & $2,53^{\mathrm{tn}}$ & $0,33^{\text {tn }}$ & $0,97^{\text {tn }}$ & $0,31^{\text {tn }}$ \\
\hline \multirow[t]{6}{*}{ Keterangan } & $\operatorname{tn}$ & \multicolumn{4}{|c|}{ : tidak berbeda nyata pada taraf 5\% } & $*$ & \multicolumn{3}{|c|}{ : berbeda nyata pada taraf $5 \%$} \\
\hline & $\mathrm{F}_{0,05}$ & \multicolumn{2}{|c|}{$: 4,60$} & & & TT & \multicolumn{3}{|c|}{ : Tinggi Tanaman; } \\
\hline & TKD & \multicolumn{4}{|c|}{ : Tingkat Kehijauan Daun } & UB & \multicolumn{3}{|c|}{ : Umur Berbunga; } \\
\hline & $\mathrm{BKB}$ & \multicolumn{4}{|c|}{ : Bobot Kering Brangkasan } & PT & \multicolumn{3}{|c|}{ : Panjang Tongkol; } \\
\hline & DT & \multicolumn{4}{|c|}{ : Diameter Tongkol } & B100 & \multicolumn{3}{|c|}{ : Bobot 100 Butir } \\
\hline & $\mathrm{HP}$ & \multicolumn{4}{|c|}{ : Hasil Pipilan } & & & & \\
\hline
\end{tabular}

Hasil pipilan jagung pada pola monokultur lebih tinggi dibanding pola tanam tumpangsari dengan selisih $-0,12 \mathrm{~cm}$. Hal ini disebabkan karena pola tanam monokultur memiliki jarak antar tanaman yang merata, daun tidak saling tumpang tindih, dan akar tanaman tidak terlalu rapat sehingga tidak terjadi persaingan dalam memperoleh unsur hara di dalam tanah. Sejalan dengan penelitian Buhaira (2007), diketahui hasil jagung pada pengaturan tanam berbaris tunggal sebesar 2,14 t/ha lebih tinggi dibandingkan pengaturan tanam berbaris ganda dan berbaris tiga sebesar 1,83 t/ha dan 1,81 t/ha.

Hasil penelitian menunjukkan bahwa penerapan pupuk urea pada tumpangsari jagung "double row" dan kacang tanah berpengaruh terhadap tingkat kehijauan daun, bobot kering brangkasan, dan hasil pipilan jagung dalam ton per hektar (Tabel 1).

Setiap peningkatan $1 \mathrm{~kg} / \mathrm{ha}$ urea mampu meningkatkan tingkat kehijauan daun sebesar 0,027 g (Gambar 1). Berdasarkan hasil penelitian Faozi dan Wijonarko (2010) yang menyatakan bahwa dengan pemupukan nitrogen dosis $150 \mathrm{~kg}$ urea/ha mampu meningkatkan kandungan klorofil a dan b pada tanaman padi sawah. Semakin tinggi kandungan klorofil dalam daun tanaman maka warna daunnya semakin hijau gelap sehingga tingkat kehijauan daun semakin tinggi. Hal ini sejalan dengan peranan $\mathrm{N}$ bagi tanaman, yaitu merangsang pertumbuhan dan memberikan warna hijau pada daun (Subandi et al., 2008).

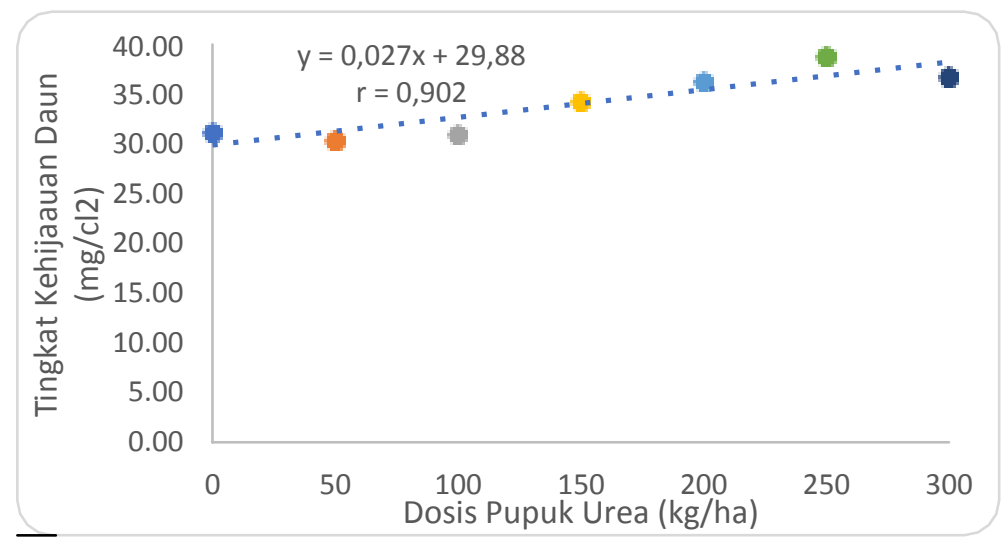

Gambar 1. Pengaruh pupuk urea pada tumpangsari jagung "double row" dan kacang tanah terhadap tingkat kehijauan daun 
Bobot kering brangkasan meningkat secara linear dengan pemberian dosis pupuk Urea. Setiap peningkatan $1 \mathrm{~kg} / \mathrm{ha}$ urea mampu meningkatkan bobot kering brangkasan sebesar 0,0019 (Gambar 2).

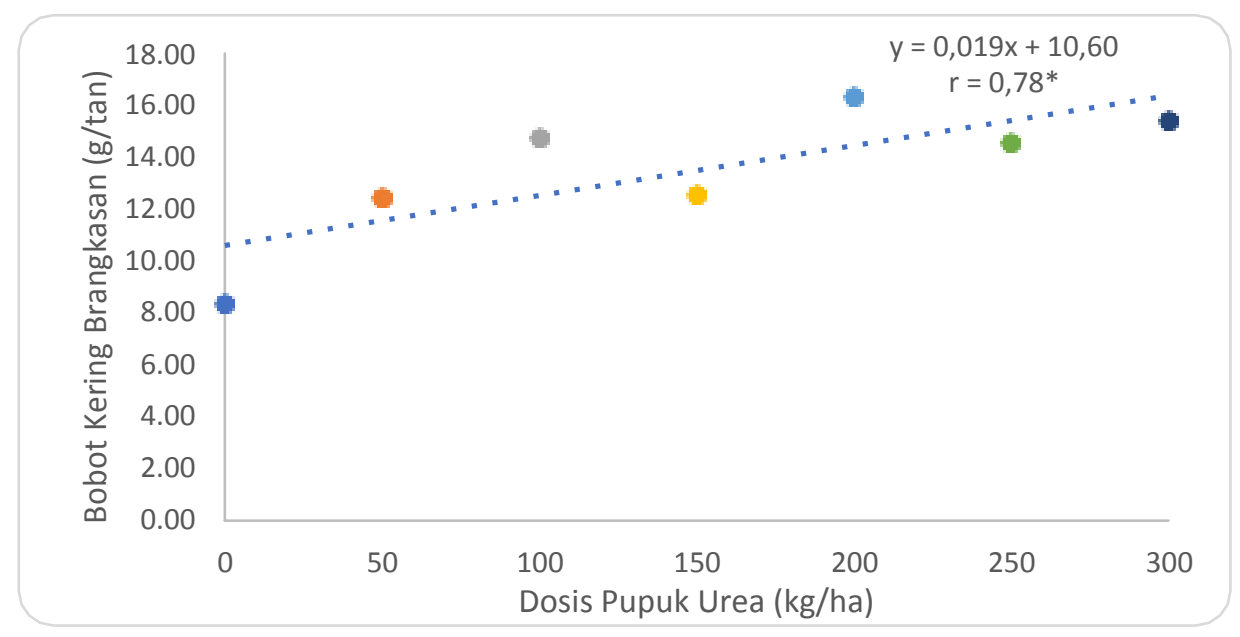

Gambar 2. Pengaruh pupuk urea pada tumpangsari jagung "double row" dan kacang tanah terhadap bobot kering brangkasan

Hasil penelitian Pratama (2014) yang menyatakan bahwa pemberian pupuk urea dengan $150 \mathrm{~kg} / \mathrm{ha}$ dan $300 \mathrm{~kg} / \mathrm{ha}$ menghasilkan bobot brangkasan kering jagung. Pemberian pupuk urea $300 \mathrm{~kg} / \mathrm{ha}$ secara nyata lebih tinggi daripada pupuk urea $150 \mathrm{~kg} / \mathrm{ha}$. Sejalan dengan penelitian Putra dkk (2015), pengaruh aplikasi pupuk urea pada taraf $100 \mathrm{~kg} / \mathrm{ha}$ hingga $300 \mathrm{~kg} / \mathrm{ha}$ mampu meningkatkan bobot kering tajuk tanaman secara nyata. Hal serupa juga diungkapkan oleh Suwardi dan Roy (2009) yang menyatakan bahwa pemberian N yang semakin tinggi dapat mempengaruhi tinggi tanaman jagung pada fase V9 (42 HST) dan bobot kering berangkasan. Semakin tinggi pemberian N maka semakin besar tinggi tanaman dan bobot kering berangkasan.

Selain itu, pemberian pupuk urea juga meningkatkan hasil pipilan jagung secara linier. Adanya pengaruh tersebut menunjukkan bahwa setiap peningkatan $1 \mathrm{~kg}$ dosis pupuk urea akan meningkatkan hasil pipilan jagung sebesar 0,001 t/ha atau setara dengan $1 \mathrm{~kg} / \mathrm{ha}$ (Gambar 3).

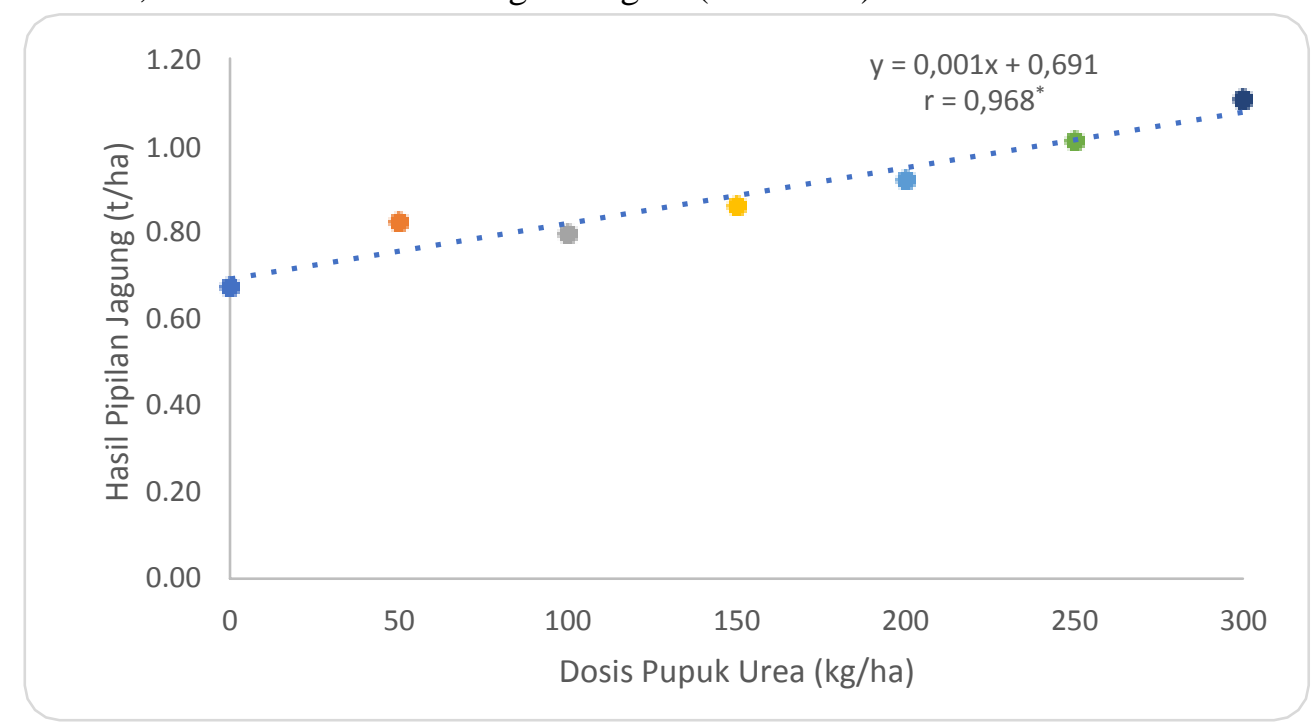

Gambar 3. Pengaruh pupuk urea pada tumpangsari jagung "double row" dan kacang tanah terhadap hasil pipilan jagung 
Gadmor, M.S dkk : Penerapan Pupuk Urea pada Tumpangsari Jagung “Double Row” dan Kacang Tanah...

Hal ini berarti bahwa semakin tersedianya nitrogen bagi tanaman akan meningkatkan hasil pipilan jagung. Mapegau (2010) juga menyatakan bahwa pemupukan nitrogen sangat mempengaruhi hasil biji kering tanaman jagung. Dalam penelitiannya, diketahui dengan pemberian pupuk $\mathrm{N}$ sebanyak $90 \mathrm{~kg} / \mathrm{ha}$ atau setara dengan $196 \mathrm{~kg}$ urea/ha mampu meningkatkan hasil biji kering jagung sebesar 2,97 t/ha.

Hasil penelitian menunjukan bahwa tumpangsari jagung "double row" dan kacang tanah berpengaruh terhadap tinggi tanaman, tingkat kehijauan daun, jumlah polong isi, bobot 100 butir dan hasil biji kacang tanah (Tabel 2).

Tabel 2. Penerapan pupuk urea pada tumpangsari jagung "double row" dan kacang tanah terhadap tinggi tanaman, tingkat kehijauan daun, jumlah cabang produktif, jumlah polong isi, bobot 100 butir, hasil biji kacang tanah.

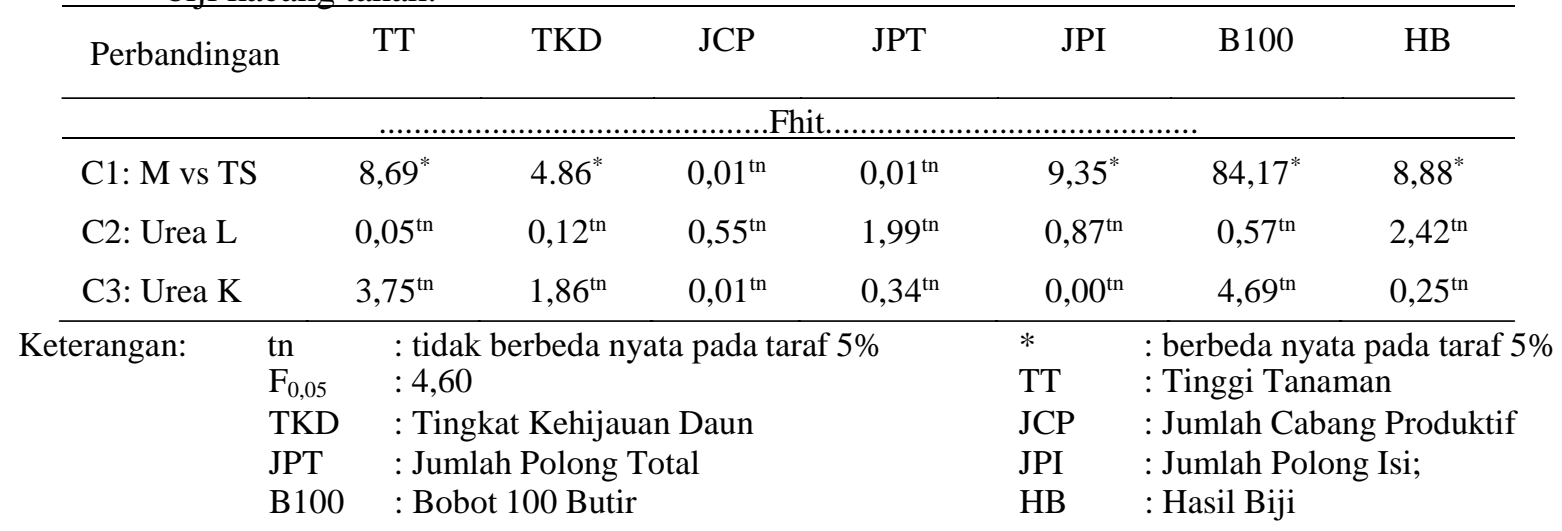

Tinggi tanaman kacang tanah pada pola tanam tumpangsari lebih tinggi dibandingkan pola tanam tumpangsari dengan selisih $6,03 \mathrm{~cm}$. Tinggi tanaman pada penelitian ini berkisar antara $35-42 \mathrm{~cm}$. Sedangkan pertumbuhan normal tinggi tanaman pada kacang tanah hanya $30 \mathrm{~cm}$ (Weiss 1983). Hal ini disebabkan karena tanaman kacang tanah mendapat naungan dari tanaman jagung. Sesuai dengan penelitian Susanto dan Sundari (2011) yang menyatakan bahwa tanaman kedelai yang tumbuh dengan lingkungan ternaungi memiliki tinggi tanaman yang lebih tinggi dibandingkan tanpa naungan. Rata-rata tinggi tanaman yang ternaungi sebesar 58,6 $\mathrm{cm}$ sedangkan tanpa naungan sebesar 50,2 $\mathrm{cm}$. Tanaman kacang tanah yang mendapatkan naungan akan mengalami pemanjangan sel mendorong batang tanaman tumbuh lebih cepat yang disebabkan distribusi auksin yang tinggi (Gardner et al., 1985).

Sedangkan tingkat kehijauan daun, jumlah polong isi, bobot 100 butir, dan hasil biji kacang tanah pada pola tanam monokultur lebih tinggi dibanding pola tanam tumpangsari dengan selisih $-3,11 \mathrm{~cm}$ pada tingkat kehijauan daun dan bobot 100 butir, $-0,65 \mathrm{~cm}$ pada jumlah polong isi, dan $-0,05 \mathrm{~cm}$ pada hasil biji per hektar . Hal ini diduga karena pada pola tanam tumpangsari terjadi persaingan atau kompetisi antar tanaman. Indayani et al. (2000) menjelaskan bahwa kompetisi terjadi apabila tanaman mencapai tingkat pertumbuhan tertentu dan semakin keras dengan pertambahan ukuran tanaman dengan umur. Kemampuan suatu tanaman dipengaruhi oleh suatu organ tanaman yang melakukan kompetisi. Daun dan akar adalah bagian organ tanaman yang berperan aktif dalam melakukan kompetisi. Daun yang lebar dan banyak serta tersebar di seluruh bagian tanaman akan meningkatkan kompetisi atau persaingan sehingga dapat menurunkan hasil tanaman.

\section{KESIMPULAN}

Berdasarkan hasil penelitian maka didapatkan kesimpulan bahwa (1) hasil pipilan jagung per hektar untuk monokultur lebih tinggi daripada tumpangsari, tetapi semua variabel lainnya tidak berbeda. Sedangkan hasil kacang tanah monokultur lebih tinggi daripada tumpangsari "double row" untuk jumlah polong isi, bobot 100 butir, dan bobot biji per hektar, tetapi untuk tinggi tanaman dan tingkat kehijauan daun pola tumpangsari 
"double row" lebih tinggi daripada monokultur, (2) belum didapatkan dosis pupuk Urea yang optimal untuk tanaman jagung pada pola tanam tumpangsari jagung "double row" dan kacang tanah.

\section{DAFTAR PUSTAKA}

Badan Pusat Statistik. 2014. Produksi, Luas Panen, dan Produktivitas Jagung Indonesia. Badan Pusat Statistika. Jakarta.

Buhaira, 2007. Respon Kacang Tanah (Arachis hypogaea L.) dan Jagung (Zea mays L.) Terhadap Beberapa Pengaturan Tanam Jagung pada Sistem Tanam Tumpangsari. Jurnal Agronomi 11 (1) : 41-46.

Faozi, Khavid dan Bambang Rudianto Wijonarko. 2010. Serapan Nitrogen dan Beberapa Sifat Fisiologi Tanaman Padi Sawah dari Berbagai Umur Pemindahan Bibit. Jurnal Pembangunan Pedesaan Vol 10 (2) ; 93-101 hlm.

Gardner, F.R., R.B. Pearce and R.L. Mitchell. 1985. Fisiologi Tanaman Budidaya. Gadjah Mada Press. 428 hlm.

Indayani, Neny, Nasrullah, dan D. Priyanto. 2000. Kegiatan Biometrika Daya Saing antara Varietas Kedelai pada Pertanaman Campuran dan Baris Berseling. Agrosains 13 (2) : 183-184.

Jumin, Hasan B. 2010. Dasar-Dasar Agronomi. PT Raja Grafindo Persada. Jakarta. 46-48 hlm.

Lingga, P., dan Marsono. 2008. Petunjuk Penggunaan Pupuk. Penebar Swadaya: Jakarta. $150 \mathrm{hlm}$

Mapegau. 2010. Pengaruh Pemupukan N dan P Terhadap Pertumbuhan dan Hasil Tanaman Jagung. Jurnal Penelitian Univerisitas Jambi Seri Sains 12 (2) : hal 33-36.

Myrna, Nyimas E.F. dan Puji Lestari. A. 2010. Peningkatan Efisiensi Konversi Energi Matahari pada Pertanaman Kedele Melalui Penanaman Jagung dengan Jarak Tanam Berbeda. Jurnal Penelitian Universitas Jambi Seri Sains 12 (2) : 49-54.

Pratama, M.S. 2014. Tumpangsari Tanaman Jagung dan Kacang Tanah Terhadap Pertumbuhan dan Hasil Jagung dengan Penerapan Pupuk Urea (Skripsi). Hal 45-46.

Putra, A.D., M.M.B. Damanik, dan H. Hanum. 2015. Aplikasi Pupuk Urea dan Pupuk Kandang Kambing untuk Meningkatkan N-Total pada Tanah Inceptisol Kwala Bekala dan Kaitannya Terhadap Pertumbuhan Tanaman Jagung (Zea mays L.). Jurnal Online Agroteknologi Vol 3 (1) : 128-135.

Subandi, Marwoto, dan Kuntyastuti H. 2008. Kesiapan teknologi mendukung peningkatan produksi menuju swasembada kedelai. hal. 188-219. Prosiding Simposium V Tanaman Pangan. Bogor 28-29 Agustus 2007.

Susanto, Gatut Wahyu Anggoro dan Titik Sundari. 2011. Perubahan Karakter Agronomi Aksesi Plasma Nutfah Kedelai di Lingkungan Ternaungi. Jurnal Agronomi Indonesia 39 (1) : 1-6 .

Suwardi dan Roy Effendi. 2009. Efisiensi Penggunaan Pupuk N pada Jagung Komposit Menggunakan Bagan Warna Daun. Balai Penelitian Tanaman Serealia. 115 hlm.

Tangedjaja, B. dan E. Wina. 2011. Limbah Tanaman dan Produk Sampingan Industri Jagung Untuk Pakan. Balai Penelitian Ternak. Bogor.

Weiss, E.A. 1983. Oil Seed Crops.Longman Inc. New York. USA. 